\title{
Promoting Physical Activity and Healthy Nutrition in Children and Adolescents: a Report on a Nationally Coordinated Program in Switzerland
}

\author{
Thomas Mattig, JD, MPH \\ Health Promotion Switzerland, Bern, and Institute of Global Health, University of Geneva, Geneva, Switzerland \\ *Corresponding Author : Prof. Thomas Mattig, Health Promotion Switzerland/Gesundheitsförderung \\ Schweiz, Wankdorfallee 5, 3014 Bern, Switzerland. Email: Thomas.Mattig@promotionsante.ch
}

\begin{abstract}
Overweight and obesity prevalence rates are high in Switzerland, as in most industrialized countries. Keeping children and adolescents slim must therefore be a public health priority.

In 2007 Health Promotion Switzerland launched a national prevention program targeting children and adolescents as well as parents, teachers and caregivers that focused on promoting physical activity and healthy nutrition behaviors. Over the years, several hundred local and regional projects were implemented in close collaboration with the cantons: hundreds of thousands of children and adolescents were reached as well as tens of thousands of multipliers in several thousand settings (schools, daycare centers, community centers, families, etc.).

The data that were collected over the years showed a slight reduction in the share of overweight and obese children and adolescents and a slight increase in healthy eating behaviors among adolescents. There was no significant change in daily physical activity over the time period studied for any given age, but there was an important drop between childhood and late adolescence.

In conclusion, even though the CAPs design does not allow to conclude that the slight behavioral changes observed are directly linked to the program, it is worth noting, in a health policy perspective, that the program allowed the implementation of a multitude of health promoting activities in good coordination between various stakeholders at local, regional and federal levels.
\end{abstract}

Keywords: Children, adolescents physical activity, healthy nutrition, health promotion, prevention

\section{INTRODUCTION}

\subsection{Overweight and Obesity in childhood and adolescence}

Worldwide, the prevalence of childhood overweight and obesity has increased dramatically over the past decades [1]. Indeed, the increase has been especially significant in young children, as the World Health Organization (WHO) reported: "The number of overweight or obese infants and young children (aged 0 to 5 years) increased from 32 million globally in 1990 to 41 million in 2016"[2]. The increase has been even more notable in older children and adolescents, with the WHO reporting: "The prevalence of overweight and obesity among children and adolescents (aged 5-19) has risen dramatically from 4\% in 1975 to just over $18 \%$ in 2016. [...] While just under 1\% of children and adolescents were obese in 1975, nearly 7\% were obese by 2016" [3].

Early overweight and obesity are major risk factors for a variety of health problems in adulthood, such as type 2 diabetes, cancer, cardiovascular disease, musculoskeletal disorders and disabilities, thus heavily contributing to the global disease burden [4]. Indeed, the maintenance of a healthy body weight from early childhood on represents a major public health challenge [5].

The WHO Global Strategy on Diet, Physical Activity and Health indicates that a "combination of sound and effective actions is needed at global, regional, national and local levels" [6] to improve diets and increase physical activity [6]. When, in 2014, the World Health Assembly adopted the Global Action 
Plan 2013-2020 for the prevention and control of non-communicable diseases [7], it de facto further strengthened the objective of halting the global obesity rates in school-aged children, adolescents and adults. During the last decade of the $20^{\text {th }}$ century and the first decade of the $21^{\text {st }}$ century, only a few local or regional studies in Switzerland investigated the body weight of children and adolescents, and they reported a prevalence of overweight and obesity of $15 \%$ to $19 \%[8,9,10]$, a substantial increase when compared to data from half a century ago. Indeed, one particular study [11] reported a fiveto six-fold increase when comparing the data of their 2002 study of a representative national sample of 1,196 boys and 1,235 girls aged 6 to 12 years using the IOTF BMI references to data of the first Zurich Longitudinal Study (1960-65) [12] and the second Zurich Longitudinal Study (1980-90) [13]: they observed 16.6\% overweight and $3.8 \%$ obese boys as well as $19.1 \%$ overweight and $3.7 \%$ obese girls (mean age 9.8 years). The authors concluded that it is important to fight such an epidemic of overweight and obesity in children and adolescents.

\subsection{Health Promotion in Switzerland}

In a federal state such as Switzerland - which is composed of 26 cantons fiercely attached to their independence in policy matters-disease prevention and health promotion as well as health care are within the purview of public authorities at three levels: the Confederation, the cantons and the municipalities [14]. In such a complex system, coordination is key for delivering effective and efficient services to the public, a fact stressed by international evaluations $[15,16]$. In 1989, the federal authorities, the cantons and the health insurance companies decided to create a foundationcalled Health Promotion Switzerland in its current incarnation - intended to initiate and coordinate health promotion activities at the national level [17].

During the period of its strategic plan 20072018, the foundation initiated and coordinated many health promotion programs, not ably the one focusing on healthy nutrition and physical activity among children and adolescents presented below [18]. This program was considered a public health priority of national importance, since it is well documented that the longer the period of obesity in early childhood, the greater the probability of adulthood obesity
[19], which in turn increases the risk of developing a chronic non-communicable disease [20]. Similarly, it has been shown that the risk of overweight adolescents to be overweight adults two decades later increases five- to sevenfold [21]. The promotion of physical activity and healthy eating behaviors was chosen because the literature suggests that this is the approach most likely to have the most beneficial health effects in the long run $[22,23$, $24,25,26]$.

\section{CASe Report}

We present hereafter part of the Cantonal Action Programs (CAPs), cantonal health promotion activities coordinated by Health Promotion Switzerland, specifically focusing on the health promotion interventions aimed at promoting physical activity and healthy eating behaviors among children and adolescents (further details are available in reference 27).

Indeed, since 2007, the issues of physical activity and healthy nutrition have been a major focus of Health Promotion Switzerland's strategy, with the aim of increasing the share of the population with a healthy body weight. The CAPs are key to this strategy. With the financial and technical support of Health Promotion Switzerland, the CAPs implement activities at four levels: the intervention level covers interventions for specific target groups, e.g., children and adolescents, as well as multipliers; the policy level refers to measures, most often structural in nature, designed on a large scale; the networking level emphasizes the intracantonal and inter-cantonal collaboration between the different actors; and lastly, the public information level aims to raise public awareness of the challenges to achieving and maintaining a healthy body weight. Table I summarizes the main objectives of the CAPs, which have been slightly adapted over the years [27].

Table II lists four examples of emblematic interventions aiming at promoting physical activity and healthy nutrition specifically targeting children, adolescents and multipliers that have taken place over the years:

- "Purzelbaum" (somersault), which promotes exercise and healthy nutrition in kindergarten and daycare;

- "Gorilla," which pursues identical objectives but targets older children and adolescents 
through different means (website, workshops, cooking classes, etc.);

- "Pédibus" takes children to school on foot with an accompanying parent; and "Fourchette verte" (green fork) offers healthy meals at school cafeterias

Table III shows the number of individuals reached in the respective target groups, which increased over the years due to the continuous efforts by cantonal and municipal authorities as well as Health Promotion Switzerland, which provided a mean annual budget of roughly 9 million Swiss francs.

Tables IV \& V show some results of outcome evaluations that were implemented at regular intervals:

- Archimi et al. [28] report a slight increase in healthy eating behaviors among adolescents;
- Stamm et al. [29] report a slight reduction of the proportion of overweight and obese children and adolescents; they also report a higher share of overweight among children and adolescents of immigrant origin (24\% vs. $14 \%)$; an even more important difference is observed between children and adolescents of parents with only compulsory education versus parents with higher (tertiary) education (30\% vs. $10 \%)$;

- Archimi et al. [28] report a slight increase in adolescents mentioning some daily physical activity. Lamprecht et al. [30], using a different data-collecting methodology, do not corroborate this finding, while Bringolf-Isler et al. [31] observe a significant drop in daily physical activity with advancing age: while $100 \%$ of 6-7-year-olds report moving one hour per day, only $22 \%$ of $14-16$-year-olds report the same.

Table I. Main objectives of the Cantonal Action Programs (CAPs) at the different activity levels over the years

\begin{tabular}{|l|l|}
\hline \multicolumn{1}{|c|}{ Level } & \multicolumn{1}{c|}{ Main objectives } \\
\hline Intervention & Interventions are increasingly and permanently anchored in existing or new structures \\
\hline \multirow{4}{*}{ Policy } & $\begin{array}{l}\text { Interventions are evaluated on a regular basis and focus on the target groups (children, } \\
\text { adolescents and multipliers) }\end{array}$ \\
\hline \multirow{3}{*}{ Networking } & $\begin{array}{l}\text { Promotion of physical activity and healthy nutrition is increasingly structurally anchored } \\
\text { in the cantons }\end{array}$ \\
\hline & Policymakers are committed to promoting physical activity and healthy eating habits \\
\hline \multirow{2}{*}{ Communication } & $\begin{array}{l}\text { In a majority of the cantons a close collaboration with the respective education } \\
\text { department has been established (to provide access to schools) }\end{array}$ \\
\cline { 2 - 3 } & $\begin{array}{l}\text { Active networking within cantons and among cantons has been implemented } \\
\text { public (e.g., impact of soft drinks on body weight) }\end{array}$ \\
\hline \multirow{2}{*}{ Outcome } & $\begin{array}{l}\text { The number of persons reached in the various target groups has increased } \\
\text { The healthy behaviors of children and adolescents regarding nutrition and physical } \\
\text { activity have improved }\end{array}$ \\
\cline { 2 - 3 } & The share of overweight or obese children remains stable or has even decreased \\
\hline
\end{tabular}

Table II. Examples of interventions aiming at promoting physical activity and health nutrition among children and adolescents

\begin{tabular}{|c|c|c|c|c|}
\hline $\begin{array}{c}\text { Project } \\
\text { Name }\end{array}$ & Project objectives & Outreach & $\begin{array}{c}\text { Outcome } \\
\text { multipliers }\end{array}$ & $\begin{array}{c}\text { Outcome } \\
\text { children \& } \\
\text { adolescents }\end{array}$ \\
\hline $\begin{array}{l}\text { Purzelbaum } \\
\text { (somersault) }\end{array}$ & $\begin{array}{l}\text { "Purzelbaum" anchors } \\
\text { versatile exercises, } \\
\text { balanced nutrition and } \\
\text { resource-strengthening } \\
\text { offerings in the everyday } \\
\text { life of primary schools and } \\
\text { kindergartens as well as } \\
\text { daycare centers and play } \\
\text { groups through simple and } \\
\text { practical means. }\end{array}$ & $\begin{array}{l}\text { 59,000 children } \\
3,900 \text { teachers } \\
\text { 3,067 kindergartens/ } \\
\text { schools/day-care } \\
\text { centers }\end{array}$ & $\begin{array}{l}90 \% \text { consciously } \\
\text { use exercise as a } \\
\text { pedagogical tool } \\
71 \% \text { address the } \\
\text { topic of exercise at } \\
\text { parent-teacher } \\
\text { conferences } \\
55 \% \text { of teachers }\end{array}$ & $\begin{array}{l}97 \% \text { of children } \\
\text { are braver when } \\
\text { it comes to } \\
\text { physical } \\
\text { activities } \\
97 \% \text { move more } \\
82 \% \text { have more } \\
\text { fun exercising }\end{array}$ \\
\hline
\end{tabular}


Promoting Physical Activity and Healthy Nutrition in Children and Adolescents: A Report on a Nationally Coordinated Program in Switzerland

\begin{tabular}{|c|c|c|c|c|}
\hline & & & $\begin{array}{l}\text { organize a parent- } \\
\text { child exercise } \\
\text { activity every year }\end{array}$ & $\begin{array}{l}58 \% \text { eat a } \\
\text { balanced snack }\end{array}$ \\
\hline Gorilla & $\begin{array}{l}\text { Through workshops, a } \\
\text { website, a cookbook and } \\
\text { educational videos, the } \\
\text { project promotes healthy } \\
\text { eating behaviors as well as } \\
\text { exercise and sports }\end{array}$ & $\begin{array}{l}24,025 \\
\text { children/adolescents } \\
527 \text { teachers }\end{array}$ & & $\begin{array}{l}82 \% \text { intend to } \\
\text { move more, } 54 \% \\
\text { intend to try new } \\
\text { recipes, } 40 \text { eat } \\
\text { more fruit, } 25 \% \\
\text { consume fewer } \\
\text { sweets, } 10 \% \text { start } \\
\text { a new sport }\end{array}$ \\
\hline Pédibus & $\begin{array}{l}\text { The "Pédibus" takes a } \\
\text { group of children on foot } \\
\text { to school or kindergarten } \\
\text { and picks them up again, } \\
\text { accompanied by an adult. }\end{array}$ & $\begin{array}{l}3,000 \text { children use } \\
\text { the Pédibuson a } \\
\text { daily basis } \\
1,600 \text { adults escort } \\
\text { the children } \\
1,500 \text { "Pédibus } \\
\text { Lines" have been } \\
\text { founded }\end{array}$ & 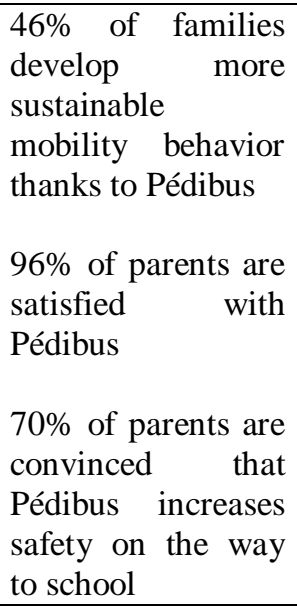 & \\
\hline $\begin{array}{l}\text { Label } \\
\text { Fourchette } \\
\text { verte } \\
\text { (green fork) }\end{array}$ & $\begin{array}{l}\text { "Fourchette verte" is a } \\
\text { quality and health label for } \\
\text { restaurants and cafeterias } \\
\text { that offer balanced meals } \\
\text { based on the Swiss food } \\
\text { pyramid. } \\
\text { The label Fourchetteverte } \\
\text { exists for toddlers (1 to } 4 \\
\text { years old) in daycare } \\
\text { centers \& children's living } \\
\text { spaces. } \\
\text { The label also exists for } \\
\text { older children (Fourchette } \\
\text { verte Junior for ages } 4 \text { to } \\
20 \text { years) in school } \\
\text { cafeterias and student } \\
\text { accommodations. }\end{array}$ & 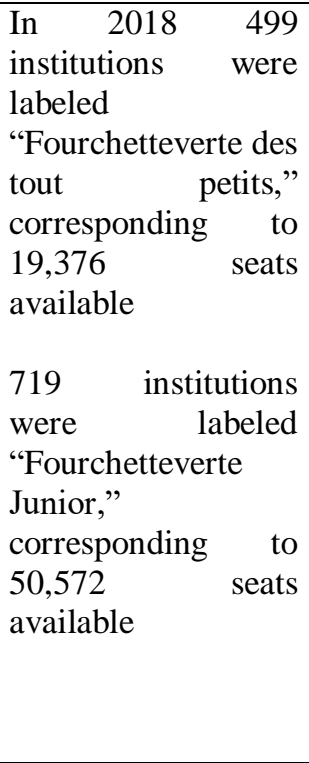 & & \\
\hline
\end{tabular}

Table III. Number of children/adolescents/multipliers reached in various settings over the years

\begin{tabular}{|l|c|c|c|}
\hline \multicolumn{1}{|c|}{ Year } & $\mathbf{2 0 1 1}$ & $\mathbf{2 0 1 3}$ & $\mathbf{2 0 1 7}$ \\
\hline Children/adolescents & 132,792 & 177,902 & 526,027 \\
\hline Multipliers & 2,200 & 2,121 & 32,821 \\
\hline Settings & 6,840 & 10,502 & 34,347 \\
\hline
\end{tabular}

Table IV. Outcome evaluations: changes in eating behaviors and physical activity of adolescents

\begin{tabular}{|l|c|l|c|c|}
\hline Publication & $\begin{array}{c}\text { Number of } \\
\text { participants } \\
\text { Year of Study }\end{array}$ & Age & $\begin{array}{c}\text { Share of } \\
\text { participants } \\
\text { with 1 hour } \\
\text { of daily } \\
\text { physical }\end{array}$ & Share with healthy eating behaviors \\
\hline
\end{tabular}


Promoting Physical Activity and Healthy Nutrition in Children and Adolescents: A Report on a Nationally Coordinated Program in Switzerland-A Case Report

\begin{tabular}{|c|c|c|c|c|}
\hline & & & activity & \\
\hline $\begin{array}{c}\text { Archimi et } \\
\text { al., } 2016\end{array}$ & $\begin{array}{l}5,837 \\
2010\end{array}$ & $11-15$ years & $12 \%$ & $\begin{array}{l}42 \% \text { : daily consumption of vegetables } \\
43 \% \text { : daily consumption of fruit } \\
41 \% \text { : consumption of soft drinks } \\
\text { maximum once a week } \\
95 \% \text { : consumption of hamburger/hot dog } \\
\text { maximum once a week }\end{array}$ \\
\hline $\begin{array}{c}\text { Archimi et } \\
\text { al., } 2016\end{array}$ & $\begin{array}{l}9,894 \\
2014\end{array}$ & $11-15$ years & $14 \%$ & $\begin{array}{l}45 \% \text { : daily consumption of vegetables } \\
47 \% \text { : daily consumption of fruit } \\
39 \% \text { : consumption of soft drinks } \\
\text { maximum once a week } \\
95 \% \text { : consumption of hamburger/hot dog } \\
\text { maximum once a week }\end{array}$ \\
\hline
\end{tabular}

Table V. Outcome evaluations: changes in overweight/obesity among children and adolescents

\begin{tabular}{|c|c|c|c|c|c|}
\hline Publication & $\begin{array}{l}\text { N Number of } \\
\text { individuals }\end{array}$ & Age & $\begin{array}{l}\text { Year of } \\
\text { study }\end{array}$ & $\begin{array}{c}\% \text { overweight } \\
\text { (including obese) }\end{array}$ & \% obese \\
\hline \multirow{9}{*}{$\begin{array}{c}\text { Stamm et al., } \\
2017\end{array}$} & \multirow[t]{9}{*}{23,694} & 5-7 years & 2010 & 15.8 & 4.1 \\
\hline & & & 2013 & 12.6 & 3.0 \\
\hline & & & 2017 & 11.1 & 2.7 \\
\hline & & 9-11 years & 2010 & 19.1 & 3.2 \\
\hline & & & 2013 & 18.2 & 3.9 \\
\hline & & & 2017 & 16.5 & 3.0 \\
\hline & & $14-15$ years & 2010 & 20.5 & 4.7 \\
\hline & & & 2013 & 20.5 & 4.9 \\
\hline & & & 2017 & 21.5 & 4.8 \\
\hline
\end{tabular}

\section{DISCUSSION}

As shown in the outcome evaluations of the cantonal action programs that were developed and implemented over the last decade across Switzerland, there seems to be a trend towards stabilization or even decline in overweight/ obesity prevalence among children and adolescents over the past decade, yet the overall prevalence rates remain high. From a public health perspective, these are encouraging developments ,"even though the underlying causes of the change are not yet clear" as Jeannot et al. suggest; "the hypotheses range from the effect of prevention and public awareness to a change in body image" [32]. Similar trends have been reported from several European countries, albeit with important between-country differences [33, 34]. For example, our data differ from recent results reported by U.S. researchers, who mention " $a$ continued upward trend with significant increases in obesity and severe obesity in children aged 2 to 5 years and adolescent females aged 16 to 19 years from 2015 to 2016 " in their nationally representative U.S. sample [35]. Socioeconomic differences persist in the prevalence of overweight and obesity among children and adolescents, as data reported by Stamm et al. [29] show. Similar data has been reported by several authors from different countries [36, 37]. This is a factor that has to be taken into consideration if effectiveness and efficiency are to be improved in overweight/obesity prevention strategies.

On the other hand, we have observed a slight improvement in eating habits, especially with regard to adolescents, who over the years seem to eat more fruits and vegetables on a regular basis. Our observations are in line with the conclusion of a systematic review of multi component interventions that promoted a healthy diet in school-aged children in European Union countries, i.e., that such interventions may have "a positive impact on self-reported dietary behavior” [38].

Data regarding the increase in physical activity related to the CAPs interventions were less conclusive, based on the outcome measures. Yet qualitative data from various projects, such as the aforementioned "Pédibus" and "Purzelbaum" projects (Table II), suggest increased daily physical activity in all participating groups. This is all the more important since it is well documented that regular physical activity provides significant health benefits for young people, be it in terms of cardiovascular fitness, overweight/obesity 
prevention, bone and muscular strength as well as improved overall well-being [39, 40].

\section{CONCLUSION}

Though the CAPs design does not allow concluding that the behavioral changes observed, however modest they may be, are directly linked to the program, it is worth noting, in a health policy perspective, that it allowed the implementation of a multitude of health promoting activities in good coordination between various stakeholders at local, regional and federal levels. One might also argue that structural approaches "such as limiting of access to certain foods and generating a healthpromoting environment" [32] are essential and might represent a more effective approach on the long run.

\section{REFERENCES}

[1] Wang Y. and Lobstein T. Worldwide trends in childhood overweight and obesity. Int J Pediatr Obes. 1, 11-25 (2000).

[2] WHO. Commission on Ending Childhood Obesity. Facts and figures on childhood obesity. WHO, Geneva, 2019. https:// www. who.int/endchildhood-obesity/facts/en/(ace ssed May 12, 2020)

[3] WHO. Global Health Observatory Data. Overweight and obesity. WHO, Geneva, 2019. https://www.who.int/gho/ncd/risk_factors/over weight_adolescents_text/en/(accessed May 12, 2020)

[4] Guh D.P., Zhang W., Bansback N., Amarsi Z., Birmingham C.L. and Anis A.H. The incidence of co-morbidities related to obesity and overweight: a systematic review and metaanalysis. BMC Public Health. 9, 88 (2009).

[5] Backholer K., Walls H.L, Magliano D.J. and Peeters A. Setting population targets for measuring successful obesity prevention. Am J Public Health. 100, 2033-2037 (2010).

[6] WHO World Health Assembly. Global Strategy on Diet, Physical Activity and Health. Resolution WHA57.17. Geneva, Switzerland . (2004)

[7] WHO World Health Assembly. Follow-up to the Political Declaration of the High-level Meeting of the General Assembly on the Prevention and Control of Non-communicable Diseases. Resolution WHA66.10. Geneva, Switzerland (2013).

[8] Woringer V. and Schütz Y. Obésité en Suisse: percentiles d'indice de masse corporelle (IMC) d'une population d'enfants et d'adolescents nés en 1980 à Lausanne et écart avec les normes suisses (1955). SozPraventivmed. 48, 121-132 (2003).
[9] Addor V., Wietlisbach V., Narring F. and Michaud P.A. Cardiovascular risk factor profiles and their social gradient from adolescence to age 74 in a Swiss region. Prev Med. 36, 217-28 (2003).

[10] Lasserre A.M., Chiolero A., Cachat F., Paccaud F. and Bovet P. Overweight in Swiss children and associations with children's and parents' characteristics. Obesity. 15, 2912-2919 (2007).

[11] Zimmermann M.B., Gübeli C., Püntener C. and Molinari L. Overweight and obesity in 6-12 year old children in Switzerland. Swiss Med Wkly. 134, 523-528 (2004).

[12] Gasser T., Ziegler P., Kneip A., Prader A., Molinari L. and Largo R.H. The dynamics of growth of weight, circumferences and skinfolds in distance, velocity and acceleration. Ann Hum Biol. 20, 239-259 (1993).

[13] Largo R.H., Pfister D., Molinari L., Kundu S., Lipp A. and Duc G. Significance of prenatal, perinatal and postnatal factors in the development of AGA preterm infants at five to seven years. Dev Med Child Neurol.31, 440456 (1989).

[14] Chastonay P., Simos J., Cantoreggi N. and Mattig T. Health policy challenges in a decentralized federal state: the situation in Switzerland. ARC J Public Health Community Med15. OECD and WHO. OECD reviews of health systems: Switzerland 2011. OECD Publishing.(2011). https://doi.org/10.1787/9789 264120914-en

[15] De Pietro C., Camenzind P., Sturny I., Crivelli L., Edwards-Garavoglia S., Spranger A., Wittenbecher F. and Quentin, W. Switzerland: Health system review. Health Systems in Transition. 17 (2015).

[16] Mattig T. Coordinating health promotion in a federal state over the course of 30 years: a case report from Switzerland. Health Promot Perspect. 9, 323-330 (2019).

[17] Health Promotion Switzerland. Programmes d'action cantonaux - module A. Alimentation et activité physique chez les enfants et les adolescents. https://promotionsante.ch/programm es-daction-cantonaux/alimentation-et-activitephysique/enfants-et-adolescents $\mathrm{html}$ (accesse d May 2 2020)

[18] Power C., Lake J.K. and Cole, T.J. Measurement and long-term health risks of child and adolescent fatness. Int $\mathrm{J}$ Obes Relat Metab Disord. 21, 507-526 (1997).

[19] Haslam D.W. and James, W.P. Obesity. Lancet. 366, 1197-1209 (2005).

[20] Hulens M., Beunen G., Claessens A.L., LefevreJ., Thomis M., Philippaerts R., Borms J., Vrijens J., Lysens R. and Vansant G. Trends in BMI among Belgian children, adolescents and adults from 1969 
to 1996. Int J Obes Relat Metab Disord. 25, 395-399 (2001).

[21] Wang S.S. and Brownell K.D. Public policy and obesity: The need to marry science with advocacy. Psychiatr Clin North Am. 28, 235-252 (2005).

[22] Walls H.L., Peeters A., Proietto J. and McNeil J.J. Public health campaigns and obesity - a critique. BMC Public Health. 11, 136 (2011).

[23] Jakicic J.M., Marcus B.H., Lang W. and Janney C. Effect of exercise on 24-month weight loss maintenance in overweight women. ArchIntern Med. 168, 1550-1559 (2008).

[24] Craig W.J. Health effects of vegan diets. Am J Clin Nutr. 89, 1627S-1633S (2009)

[25] Ding, E.L., Hu, F.B. Commentary: Relative importance of diet vs physical activity for health. Int J Epidemiol. 39, 209-211 (2010.

[26] Fässler S., Laubereau B., La Mantia A., Lussi I., Roose Z. and Balthasar A. Évaluation des programmes d'action cantonaux alimentation et activité physique 2014-2017. Rapport final. Document de travail 47. Health Promotion Switzerland, Bern and Lausanne, Switzerland. (2018).

[27] Archimi A., Eichenberger Y., Kretschmann A. and Delgrande Jordan M. Habitudes alimentaires, activité physique, usage des écrans et statut pondéral chez les élèves de 11 à 15 ans en Suisse - Résultats de l'enquête "Health Behaviour in School-aged Children" (HBSC) 2014 et évolution au fil du temps. Rapport de recherche No. 78. Addiction Suisse, Lausanne, Switzerland. (2016).

[28] Stamm H., Fischer A. and Lamprecht M. Vergleichendes Monitoring der Gewichtsdaten von Kindern und Jugendlichen in der Schweiz. Analyse von Daten aus den Kantonen Basel-Stadt, Bern, Graubünden, Jura, Luzern, Obwalden, St. Gallen und Uri sowie den Städten Bern, Freiburg und Zürich. Arbeitspapier 41. Health Promotion Switzerland, Bern and Lausanne, Switzerland. (2017).

[29] Lamprecht M., Fischer A., Wiegand D. and Stamm H.P. Sport Suisse 2014: Rapport sur les enfants et les adolescents. Federal Office of Sport, Macolin, Switzerland .(2015).

[30] Bringolf-Isler B., Probst-Hensch N., Kayser B. and Suggs S. Schlussbericht zur SOPHYA-Studie. Swiss TPH, Basel, Switzerland. (2016).
[31] Jeannot E., Mahler P., Duperrex O. and Chastonay, P. Evolution of overweight and obesity among 5-6-year-old schoolchildren in Geneva. Swiss Med Wkly.140:w13040 (2010).

[32] Kess A., Spielau U., Beger C., Gausche R., Vogel M., Lipek T., Körner A., Pfäffle R. and Kiess W. Further stabilization and even decrease in the prevalence rates of overweight and obesity in German children and adolescents from 2005 to 2015: a cross-sectional and trend analysis. Public Health Nutr. 20, 3075-3083 (2017).

[33] Garrido-Miguel M., Cavero-Redondo I., ÁlvarezBueno C., Rodriguez-Artalejo F., Moreno L.A., Ruiz J.R., Ahrens W. and Martínez-Vizcaíno V. Prevalence and trends of overweight and obesity in European children from 1999 to 2016. A systematic review and meta-analysis. JAMA Pediatr. 173(10):e192430 (2019).

[34] Skinner A.C., Ravanbakht S.N., Skelton J.A., Perri, E.M. and Armstrong S.C. Prevalence of obesity and severe obesity in US children, 19992016. Pediatrics.141(3):e20173459 (2018).

[35] Sundblom E., Petzold M., Rasmussen F., Callmer E. and Lissner L. Childhood overweight and obesity prevalences levelling off in Stockholm but socioeconomic differences persist. Int J Obes. 32, $1525-1530$ (2008)

[36] Magnusson M.B., Hulthén L. and Kjellgren K.I. Obesity, dietary pattern and physical activity among children in a suburb with a high proportion of immigrants. J Hum Nutr Diet. 18, 187-194 (2005).

[37] Van Cauwenberghe E., Maes L., Spittaels H., van Lenthe F.J., Brug J., Oppert J.M. andDe Bourdeaudhuij I. Effectiveness of school-based interventions in Europe to promote healthy nutrition in children and adolescents: systematic review of published and "grey" literature. $\mathrm{Br} \mathrm{J}$ Nutr. 103, 781-797 (2010).

[38] Janssen I. and LeBlanc A.G. Systematic review of the health benefits of physical activity and fitness in school-aged children and youth. Int $\mathrm{J}$ Behav Nutr Phys Act.7, 40 (2010).

[39] Strong, W.B., Malina, R.M., Blimkie, C.J., Daniels, S.R., Dishman, R.K., Gutin, B., Hergenroeder, A.C., Must, A., Nixon, P.A., Pivarnik, J.M., Rowland, T., Trost, S., Trudeau, F. Evidence based physical activity for school-age youth. J Pediatr. 146, 732-737. (2005)

Citation: Thomas Mattig, Promoting Physical Activity and Healthy Nutrition in Children and Adolescents: a Report on a Nationally Coordinated Program in Switzerland. ARC Journal of Public Health and Community Medicine. 2020; 5(2):23-29. DOI: dx.doi. org /10.20431/2456-0596.0502003.

Copyright: (C) 2020 Authors. This is an open-access article distributed under the terms of the Creative Commons Attribution License, which permits unrestricted use, distribution, and reproduction in any medium, provided the original author and source are credited. 